\title{
An epidemiological and genetic study of facial clefting in France. I Epidemiology and frequency in relatives $^{1}$
}

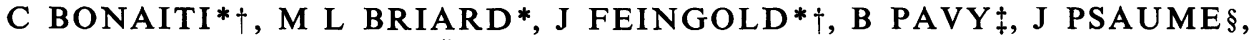 \\ G MIGNE-TUFFERAUD\|, AND J KAPLAN* \\ From the *Unité de Recherches de Génétique Médicale, INSERM, Hôpital des Enfants-Malades; \\ † Groupe de Recherches de Génétique Epidémiologique, INSERM, Château de Longchamp; \\ $\ddagger$ Clinique Chirurgicale Infantile, Hôpital des Enfants-Malades; §Service de Chirurgie Infantile, \\ Hôpital Saint Vincent de Paul; and IIService de Stomatologie et de Chirurgie Plastique et Réparatrice, \\ Hôpital Saint Antoine, Paris, France.
}

SUMMARY The frequencies of cleft lip with or without cleft palate (CL(P)) and isolated cleft palate (CP) have been estimated in France to be $0.082 \%$ and $0.035 \%$, respectively, after exclusion of malformation syndromes. A genetic and epidemiological study has been carried out on 468 patients with CL(P) and 163 with CP. The results are given in detail and some specific points are discussed: the apparently low incidence in France, the relationship between sex ratio and abortion rates, the maternal effects, and the possibility of an association between $\mathrm{CL}(\mathrm{P})$ and $\mathrm{CP}$.

The genetics of cleft lip with or without cleft palate $(C L(P))$ and isolated cleft palate (CP) have been studied by many investigators in various regions and countries. $^{1-11}$ The mode of inheritance and the role of environmental factors are not yet entirely clear. It is generally accepted that $\mathrm{CL}(\mathrm{P})$ and $\mathrm{CP}$ are developmentally and genetically different. ${ }^{12}$ These malformations may be part of genetic syndromes with Mendelian inheritance or syndromes with multiple malformations, the aetiologies of which are not clear, or syndromes resulting from chromosomal aberrations. After removal of these cases, which represent a small proportion of clefts, there remain the cases which can be explained, according to most authors, by multifactorial inheritance. However, Chung et al, ${ }^{9}$ using complex segregation analysis, and Chung et al, ${ }^{13}$ using segregation analysis under a mixed model, could not discriminate between single locus and polygenic inheritance. Melnick et $a l^{14}$ proposed allelic restriction as an alternative biological explanation.

We present the results of an epidemiological and familial investigation of cleft cases in France. In a subsequent paper, we shall perform segregation analysis on nuclear families and use recurrence risks

1Supported by a grant from Institut National de la Santé et de la Recherche Médicale (INSERM), Paris, France, ATP No 8.74.29.

Received for publication 20 March 1981 in familial cases to discriminate between modes of inheritance and to detect possible heterogeneity.

\section{Material}

There were 126087 births (including stillbirths) in various maternity hospitals in France, which provided information on stillbirths and malformation syndromes.

Familial and epidemiological information was collected for 646 probands (478 with CL(P) and 168 with CP) attending plastic surgery departments of three Paris Hospitals (Hôpital des Enfants-Malades, Hôpital Saint Vincent de Paul, Hôpital Saint Antoine). Cases of cleft associated with chromosomal aberrations, multiple malformations, or recognised syndromes were excluded from the study. Some cases came from Paris and the surrounding areas and some from other parts of France. Family information was obtained by interviews with the mother or father or both and rarely with another family member. This information included a complete pedigree extended to third degree relatives, occurrence of facial clefts or other conditions in members of the family, birth dates and places of parents and grandparents, parental consanguinity, possible problems during pregnancy, and maternal diseases. When other family cases were reported, a confirmation of the diagnosis was sought. 
TABLE 1 Frequency of clefts in the population

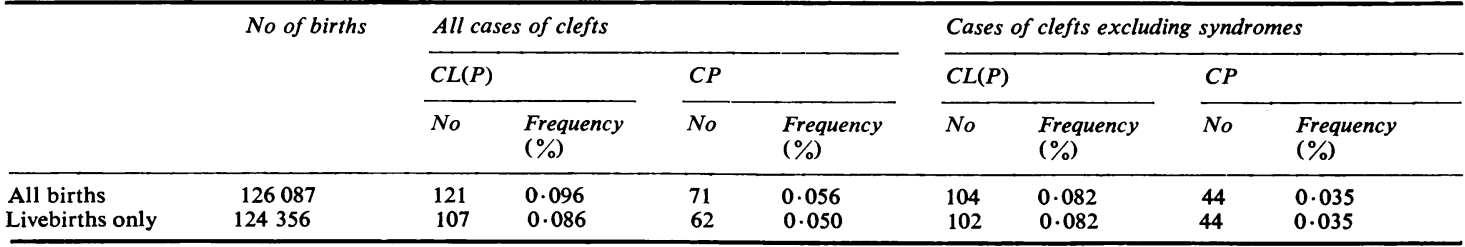

TABLE 2 Associated malformations in $478 C L(P)$ and 168 CP probands

\begin{tabular}{|c|c|c|c|}
\hline \multirow[t]{2}{*}{ Malformation } & \multicolumn{2}{|c|}{ No of cases among } & \multirow{2}{*}{$\begin{array}{l}\text { Frequency } \\
\text { in population } \\
(\%)\end{array}$} \\
\hline & $C L(P)$ & $C P$ & \\
\hline Central nervous system & $3 *$ & 0 & 0.03 \\
\hline Face & $4^{*}$ & 1 & 0.07 \\
\hline Extremities & 3 & 1 & $0 \cdot 23$ \\
\hline Skeleton & $1^{*}$ & 0 & 0.01 \\
\hline \multicolumn{4}{|l|}{ Congenital dislocation } \\
\hline of the hip & $2 *$ & $4^{*}$ & 0.04 \\
\hline Heart & 4 & 0 & 0.36 \\
\hline Diaphragm & 0 & $1 *$ & 0.004 \\
\hline Digestive system & 2 & 0 & 0.09 \\
\hline Male genitals & 2 & 0 & 0.62 \\
\hline
\end{tabular}

*Frequency significantly higher than in the French population.

TABLE 3 Composition of the series retained for the study

\begin{tabular}{llrrr}
\hline & & $C L$ & $C L+P$ & $C P$ \\
\hline Sporadic cases & Male & 58 & 193 & 48 \\
& Female & 31 & 91 & 87 \\
Familial cases & & & & \\
& Male & 18 & 42 & 15 \\
Total & Female & 12 & 23 & 13 \\
\hline
\end{tabular}

TABLE 4 Side of CL and association with $C P$

\begin{tabular}{lccccc}
\hline & \multicolumn{2}{l}{ Unilateral } & & Bilateral & Total \\
\cline { 2 - 4 } & Left & & Right & & \\
\hline CL(P) & 261 & & 95 & 112 & 468 \\
CL & & 107 & & 12 & 119 \\
CL + P & & 249 & & 100 & 349 \\
\hline
\end{tabular}

Information on other conditions in patients was obtained from medical records.

\section{Results}

POPULATION FREQUENCY (TABLE 1)

The frequency of all cases of $C L(P)$ and $C P$, including stillbirths, was estimated as 0.96 and 0.56 per 1000 , respectively. When syndromes and stillbirths were excluded, the frequency was estimated as 0.82 and 0.35 per 1000 , respectively. The frequency of malformation syndromes is much higher in stillbirths than in livebirths: $6 \cdot 9(12 / 1731)$ and $0.04(5 / 124356)$ per 1000 , respectively, for CL(P) and $5 \cdot 2(9 / 1731)$ and $0 \cdot 14(18 / 124356)$ per 1000 , respectively, for CP. When only livebirths are examined the exclusion of malformation syndromes results in a decrease in incidence from 0.86 to 0.82 per 1000 for $C L(P)$, and from $0 \cdot 50$ to $0 \cdot 35$ for CP.

\section{ASSOCIATED MALFORMATIONS}

Among the 646 probands, 21 cases of CL(P) and seven cases of $\mathrm{CP}$ had another malformation which was diagnosed at birth. For some of these malformations (table 2) the frequency in the probands is significantly higher than in the French population. ${ }^{15}$ Although the association of these malformations with CL(P) or CP did not suggest a specific syndrome, these 15 cases (ten CL(P) and five $C P$ ) were excluded from subsequent studies, in order to make the sample as homogeneous as possible. Table 3 gives the composition of the series which was finally used for the study. There were 468 cases of CL(P) from 458

TABLE 5 Sex ratio among affected and unaffected children

\begin{tabular}{|c|c|c|c|c|c|c|c|}
\hline & \multirow{2}{*}{$\begin{array}{l}\text { No of affected } \\
\text { in sibship }\end{array}$} & \multicolumn{3}{|c|}{ Affected children } & \multicolumn{3}{|c|}{ Unaffected children } \\
\hline & & Male & Female & $\%$ male & Male & Female & $\%$ male \\
\hline CL(P) & $\begin{array}{l}1 \\
2 \\
\geqslant 3 \\
\text { Total }\end{array}$ & $\begin{array}{r}291 \\
23 \\
4 \\
318\end{array}$ & $\begin{array}{r}149 \\
9 \\
3 \\
161\end{array}$ & $\begin{array}{l}0.661 \\
0.719 \\
0.571 \\
0.664\end{array}$ & $\begin{array}{r}427 \\
17 \\
4 \\
448\end{array}$ & $\begin{array}{r}397 \\
22 \\
5 \\
424\end{array}$ & $\begin{array}{l}0.518 \\
0.436 \\
0.444 \\
0.514\end{array}$ \\
\hline $\mathbf{C P}$ & $\begin{array}{l}1 \\
2 \\
\geqslant 3 \\
\text { Total }\end{array}$ & $\begin{array}{r}56 \\
6 \\
2 \\
64\end{array}$ & $\begin{array}{r}96 \\
6 \\
1 \\
103\end{array}$ & $\begin{array}{l}0.368 \\
0.500 \\
0.667 \\
0.398\end{array}$ & $\begin{array}{r}158 \\
8 \\
1 \\
167\end{array}$ & $\begin{array}{r}151 \\
10 \\
5 \\
166\end{array}$ & $\begin{array}{l}0.511 \\
0.444 \\
0.167 \\
0.502\end{array}$ \\
\hline
\end{tabular}


families and 163 cases of CP from 159 families. The total number of families is 616 because one family had two probands, one with $C L(P)$ and one with $C P$.

\section{SIDE OF CL AND ASSOCIATION WITH CP}

(TABLE 4)

Of all CL(P) probands, $24 \%$ are bilaterally affected. In unilateral cases, the left side is affected nearly three times as frequently as the right side. In $75 \%$ of cases, cleft palate is associated with cleft lip. In bilateral cases, this association is still more frequent $(89 \%)$.

\section{SEX RATIO}

As observed in Caucasian populations, $\mathrm{CL}(\mathrm{P})$ is twice as frequent in males as in females (proportion of males: 0.665 ). The same is observed when CL is associated with CP $(0.673)$ and when it is not $(0.639)$. $\mathrm{CP}$ is almost twice as frequent in females as in males (proportion of males: 0.387 ). Table 5 gives the proportion of males among affected and unaffected children according to the number of those affected in the sibship. Our results are similar to those obtained by Bear. ${ }^{16}$

In CL(P), the proportion of males among affected children does not vary significantly between sibships with one and two affected children $\left(\chi^{2}=1.91,1 \mathrm{df}\right.$, $0 \cdot 20>p>0 \cdot 10$ ), but it decreases significantly when three or more children are affected $\left(\chi^{2}=6 \cdot 59,1 \mathrm{df}\right.$, $0.02>p>0.01$ ). Among unaffected sibs, the proportion of males does not vary with the number of affected in the sibship $\left(\chi^{2}=1 \cdot 18,2 \mathrm{df}, 0 \cdot 90>p>\right.$ $0.50)$ and is similar to that in the general population.

In $\mathrm{CP}$, the proportion of males seems to increase with the number of affected children in the sibship but the variation is not significant $\left(\chi^{2}=1 \cdot 57,1 \mathrm{df}\right.$, $0 \cdot 30>p>0 \cdot 20$ ). If we pool our results with those of Bear, ${ }^{16}$ the variation is still not significant $\left(\chi^{2}=1 \cdot 67\right.$, $1 \mathrm{df}, 0 \cdot 20>\mathrm{p}>0 \cdot 10$ ). Among unaffected sibs, the proportion of males does not vary significantly with the number of affected children in the sibship $\left(\chi^{2}=1 \cdot 66,1 \mathrm{df}, 0 \cdot 20>p>0 \cdot 10\right)$, and is similar to that in the general population.

\section{FREQUENCY OF STILLBIRTHS AND}

SPONTANEOUS ABORTIONS

The proportion of stillbirths and spontaneous abortions among the other pregnancies of the mother was estimated according to sibship size (table 6) and to the number of affected children in the sibship (table 7). Sibship size was defined as the number of livebirths (and not the number of pregnancies as defined by Bear ${ }^{16}$ ). The control group was taken from Briard et al..$^{15}$ The decrease in the proportion of abortions with the number of affected children observed by Bear ${ }^{16}$ is also observed in our sample,

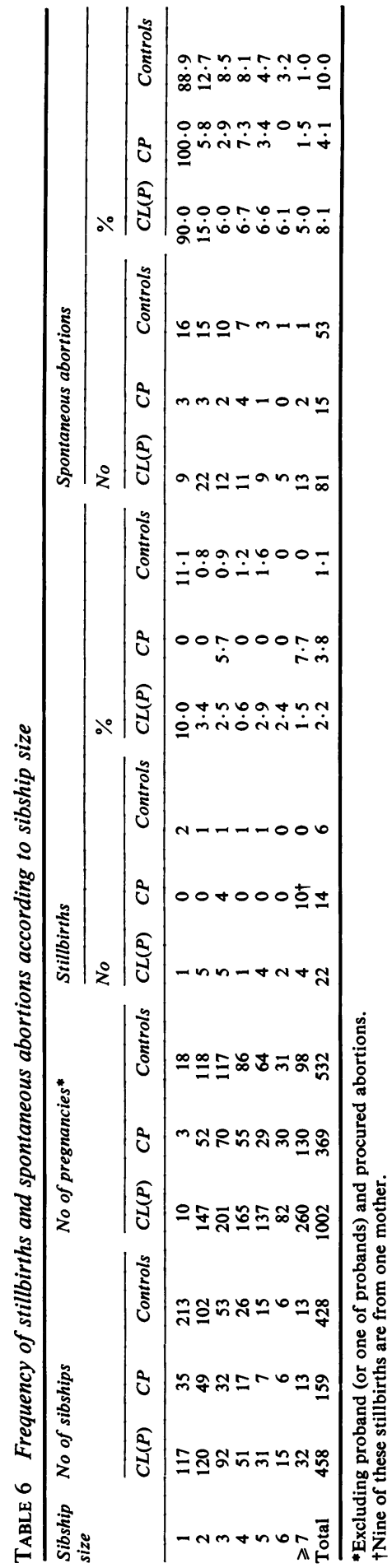


TABLE 7 Frequency of stillbirths and spontaneous abortions according to the number of affected children in sibship

\begin{tabular}{|c|c|c|c|c|c|c|c|}
\hline & \multirow{2}{*}{$\begin{array}{l}\text { No of affected } \\
\text { in sibship }\end{array}$} & \multirow{2}{*}{$\begin{array}{l}\text { No of } \\
\text { sibships }\end{array}$} & \multirow{2}{*}{$\begin{array}{l}\text { No of } \\
\text { pregnancies* }\end{array}$} & \multicolumn{2}{|c|}{ Stillbirths } & \multicolumn{2}{|c|}{ Spontaneous abortions } \\
\hline & & & & No & $\%$ & No & $\%$ \\
\hline CL(P) & $\begin{array}{r}1 \\
2 \\
\geqslant 3\end{array}$ & $\begin{array}{r}439 \\
17 \\
2\end{array}$ & $\begin{array}{r}928 \\
43 \\
9\end{array}$ & $\begin{array}{r}20 \\
2 \\
0\end{array}$ & $\begin{array}{l}2 \cdot 2 \\
4 \cdot 7 \\
0\end{array}$ & $\begin{array}{r}78 \\
3 \\
0\end{array}$ & $\begin{array}{l}8 \cdot 4 \\
7.0 \\
0\end{array}$ \\
\hline $\mathbf{C P}$ & $\begin{array}{r}1 \\
2 \\
\geqslant 3\end{array}$ & $\begin{array}{r}152 \\
6 \\
1\end{array}$ & $\begin{array}{r}337 \\
18 \\
6\end{array}$ & $\begin{array}{r}14 \\
0 \\
0\end{array}$ & $\begin{array}{l}4 \cdot 2 \\
0 \\
0\end{array}$ & $\begin{array}{c}15 \\
0 \\
0\end{array}$ & $\begin{array}{l}4 \cdot 5 \\
0 \\
0\end{array}$ \\
\hline
\end{tabular}

*Excluding affected children and procured abortions.

though it is not significant for CL(P) or for CP. A significant decrease in the proportion of abortions with sibship size is observed in CL(P) $\left(\chi^{2}=15 \cdot 78\right.$, $\left.5 \mathrm{df}^{*}, 0.01>\mathrm{p}>0.001\right)$ and in the control group $\left(\chi^{2}=12 \cdot 82,4 \mathrm{df}, 0 \cdot 02>\mathrm{p}>0 \cdot 01\right)$.

PARENTAL AGE AND BIRTH ORDER (TABLE 8) Birth 0 :der is significantly higher for $\mathrm{CP}$ and $\mathrm{CL}(\mathrm{P})$ patients than for controls ${ }^{15}(0.05>p>0.02)$. The increase is marked only for familial cases and may be the result of observation bias: the probability that another child will be affected increases with sibship size. Parental ages are not increased, except paternal age in familial cases of $\mathrm{CP}$, which is probably the result of the increase in birth order. Increased paternal ages were found by some authors, among them Fraser and Calnan ${ }^{17}$ and Woolf, ${ }^{18}$ but not in other studies.

\section{BIRTHWEIGHT (TABLE 9)}

In general, the mean birthweight is similar for cleft children and for controls, ${ }^{19}$ except for female CP

*After exclusion of sibships of size 1 .

TABLE 8 Mean parental age and birth order

\begin{tabular}{|c|c|c|c|}
\hline & Paternal age & Maternal age & Birth order \\
\hline $\begin{array}{l}\text { CL(P) } \\
\text { Sporadic } \\
\text { Familial } \\
\text { Total }\end{array}$ & $\begin{array}{l}29 \cdot 3 \pm 0 \cdot 3 \\
29 \cdot 8 \pm 0 \cdot 7 \\
29 \cdot 4 \pm 0 \cdot 3\end{array}$ & $\begin{array}{l}26 \cdot 2 \pm 0 \cdot 3 \\
26 \cdot 5 \pm 0 \cdot 5 \\
26 \cdot 2 \pm 0 \cdot 3\end{array}$ & $\begin{array}{l}2 \cdot 27 \pm 0 \cdot 09 \\
2 \cdot 64 \pm 0 \cdot 18^{*} \\
2 \cdot 35 \pm 0 \cdot 08^{*}\end{array}$ \\
\hline $\begin{array}{l}\text { CP } \\
\text { Sporadic } \\
\text { Familial } \\
\text { Total }\end{array}$ & $\begin{array}{l}30 \cdot 0 \pm 0 \cdot 6 \\
32 \cdot 4 \pm 1 \cdot 6^{*} \\
30 \cdot 3 \pm 0 \cdot 6\end{array}$ & $\begin{array}{l}26 \cdot 7 \pm 0 \cdot 5 \\
29 \cdot 4 \pm 1 \cdot 6 \\
27 \cdot 1 \pm 0 \cdot 5\end{array}$ & $\begin{array}{l}2 \cdot 52 \pm 0 \cdot 20 \\
3 \cdot 44 \pm 0 \cdot 64^{*} \\
2 \cdot 66 \pm 0 \cdot 19^{*}\end{array}$ \\
\hline Controls & $29 \cdot 6 \pm 0 \cdot 4$ & $26 \cdot 9 \pm 0 \cdot 3$ & $2 \cdot 12 \pm 0.08$ \\
\hline
\end{tabular}

*Significantly higher than controls.

TABLE 9 Mean birthweight

\begin{tabular}{llll}
\hline & $C L(P)$ & $C P$ & Controls \\
\hline Male & $3302 \pm 28$ & $3365 \pm 104$ & $3334 \pm 5$ \\
Female & $3141 \pm 44$ & $3016 \pm 54^{*}$ & $3220 \pm 5$ \\
\hline
\end{tabular}

*Significantly lower than controls where it is significantly lower $\left(10^{-3}>\mathrm{p}>10^{-4}\right)$. So far there has been no explanation for this phenomenon, which has previously been observed by Lutz ${ }^{20}$ and Fraser and Calnan. ${ }^{17}$

\section{FREQUENCY OF MALFORMATIONS IN} SIBSHIPS

The incidence of malformations at birth (excluding clefts) in sibships of children with $\mathrm{CL}(\mathrm{P})$ or $\mathrm{CP}$ is $1.4 \%$ and $0.9 \%$, respectively, no different from the general population $(1 \cdot 86 \%) .^{15}$

\section{MATERNAL EFFECTS}

Effects of maternal diseases such as epilepsy and diabetes, or events during pregnancy such as metrorrhagia, infectious diseases, drug ingestion, irradiation, etc, were studied. Comparison with a control group, collected in three Paris maternity hospitals (E Bois, personal communication), did not show any significant difference, except for epilepsy. Ten mothers of 11 probands were epileptic or had a positive history of convulsions. Five of them were treated, most of them only with phenobarbital (4/5) and one of them had two children with $C L+P$. Two mothers were not treated and the three others had convulsions but were not true epileptics. Thus, the frequency of epilepsy in mothers of probands is $1.7 \%(2.4 \%$ if mothers with a positive history of convulsions are included), which is significantly higher than in the control group $(2.5$ per 1000$)$ ( $p=0.037$ if only true epileptic mothers are considered). Among the 11 probands, five were familial cases: two of them were sibs and the three others had a more or less distant relative affected. It is interesting to note that two non-epileptic mothers received phenobarbital during pregnancy, a proportion which is not higher than in the control group $(0 \cdot 8 \%)$.

\section{FREQUENCY OF CLEFTS IN RELATIVES}

The proportion of relatives with clefts is given according to the degree of kinship (table 10), to the sex of the probands (table 11), to the relationship 
TABLE 10 Frequency of clefts in relatives according to degree of kinship

\begin{tabular}{|c|c|c|c|c|c|c|c|c|}
\hline & \multirow[t]{2}{*}{ Relatives } & \multicolumn{3}{|c|}{ 1st degree } & \multicolumn{3}{|l|}{ 2nd degree } & \multirow{2}{*}{$\frac{3 r d \text { degree }}{\text { First cousins }}$} \\
\hline & & Sibs & Parents & Total & Uncles-aunts & Grandparents & Total & \\
\hline CL(P) & $\begin{array}{l}\text { Affected } \\
\text { Total } \\
\%\end{array}$ & $\begin{array}{r}28 \\
927 \\
3 \cdot 0\end{array}$ & $\begin{array}{r}20 \\
936 \\
2 \cdot 1\end{array}$ & $\begin{array}{r}48 \\
1863 \\
2 \cdot 6\end{array}$ & $\begin{array}{r}13 \\
3058 \\
0 \cdot 4\end{array}$ & $\begin{array}{c}7 \\
1872 \\
0.4\end{array}$ & $\begin{array}{r}20 \\
4930 \\
0 \cdot 4\end{array}$ & $\begin{array}{r}18 \\
4858 \\
0.4\end{array}$ \\
\hline $\mathbf{C P}$ & $\begin{array}{l}\text { Affected } \\
\text { Total } \\
\%\end{array}$ & $\begin{array}{r}10 \\
350 \\
2 \cdot 9\end{array}$ & $\begin{array}{c}9 \\
326 \\
2 \cdot 8\end{array}$ & $\begin{array}{c}19 \\
676 \\
2 \cdot 8\end{array}$ & $\begin{array}{c}8 \\
1042 \\
0 \cdot 8\end{array}$ & $\begin{array}{c}3 \\
652 \\
0.5\end{array}$ & $\begin{array}{r}11 \\
1694 \\
0.6\end{array}$ & $\begin{array}{r}6 \\
1495 \\
0.4\end{array}$ \\
\hline
\end{tabular}

TABLE 11 Frequency of clefts in relatives according to sex of probands

\begin{tabular}{|c|c|c|c|c|c|c|c|c|c|c|c|}
\hline & & \multirow[t]{2}{*}{ Relatives } & \multicolumn{3}{|c|}{ 1st degree } & \multicolumn{3}{|c|}{ 2nd degree } & \multicolumn{3}{|c|}{ 3rd degree } \\
\hline & & & $M$ & $F$ & Total & $M$ & $F$ & Total & $M$ & $F$ & Total \\
\hline CL(P) & $\begin{array}{l}\text { Male } \\
\text { probands } \\
\text { Female } \\
\text { probands }\end{array}$ & $\begin{array}{l}\text { Affected } \\
\text { Total } \\
\% \\
\text { Affected } \\
\text { Total } \\
\%\end{array}$ & $\begin{array}{c}18 \\
608 \\
3 \cdot 0 \\
9 \\
334 \\
2 \cdot 7\end{array}$ & $\begin{array}{c}14 \\
603 \\
2 \cdot 3 \\
7 \\
318 \\
2 \cdot 2\end{array}$ & $\begin{array}{c}32 \\
1211 \\
2.6 \\
16 \\
652 \\
2.5\end{array}$ & $\begin{array}{c}7 \\
1607 \\
0.4 \\
4 \\
881 \\
0.5\end{array}$ & $\begin{array}{c}6 \\
1622 \\
0.4 \\
3 \\
820 \\
0.4\end{array}$ & $\begin{array}{c}13 \\
3229 \\
0.4 \\
7 \\
1701 \\
0.4\end{array}$ & $\begin{array}{c}7 \\
1669 \\
0.4 \\
4 \\
798 \\
0.5\end{array}$ & $\begin{array}{c}4 \\
1606 \\
0.2 \\
3 \\
785 \\
0.4\end{array}$ & $\begin{array}{c}11 \\
3275 \\
0.3 \\
7 \\
1583 \\
0.4\end{array}$ \\
\hline CP & $\begin{array}{l}\text { Male } \\
\text { probands } \\
\text { Female } \\
\text { probands }\end{array}$ & $\begin{array}{l}\text { Affected } \\
\text { Total } \\
\% \\
\text { Affected } \\
\text { Total } \\
\%\end{array}$ & $\begin{array}{c}5 \\
124 \\
4 \cdot 0 \\
4 \\
211 \\
1.9\end{array}$ & $\begin{array}{c}7 \\
148 \\
4 \cdot 7 \\
3 \\
193 \\
1 \cdot 6\end{array}$ & $\begin{array}{c}12 \\
272 \\
4 \cdot 4 \\
7 \\
404 \\
1 \cdot 7\end{array}$ & $\begin{array}{c}3 \\
321 \\
0.9 \\
4 \\
537 \\
0.7\end{array}$ & $\begin{array}{c}1 \\
317 \\
0.3 \\
3 \\
519 \\
0.6\end{array}$ & $\begin{array}{c}4 \\
638 \\
0.6 \\
7 \\
1056 \\
0.7\end{array}$ & $\begin{array}{c}3 \\
275 \\
1 \cdot 1 \\
2 \\
474 \\
0.4\end{array}$ & $\begin{array}{r}0 \\
263 \\
0 \\
1 \\
483 \\
0 \cdot 2\end{array}$ & $\begin{array}{c}3 \\
538 \\
0.6 \\
3 \\
957 \\
0.3\end{array}$ \\
\hline
\end{tabular}

TABLE 12 Frequency of clefts in relatives according to the side (paternal or maternal)

\begin{tabular}{|c|c|c|c|c|c|}
\hline & Relatives & & 1st degree (parents) & 2nd degree & 3rd degree \\
\hline CL(P) & $\begin{array}{l}\text { Paternal } \\
\text { Maternal }\end{array}$ & $\begin{array}{l}\text { Affected } \\
\text { Total } \\
\% \\
\text { Affected } \\
\text { Total } \\
\%\end{array}$ & $\begin{array}{c}8 \\
468 \\
1 \cdot 7 \\
12 \\
468 \\
2 \cdot 6\end{array}$ & $\begin{array}{c}8 \\
2410 \\
0.3 \\
12 \\
2520 \\
0.5\end{array}$ & $\begin{array}{c}9 \\
2508 \\
0.4 \\
9 \\
2350 \\
0.4\end{array}$ \\
\hline CP & $\begin{array}{l}\text { Paternal } \\
\text { Maternal }\end{array}$ & $\begin{array}{l}\text { Affected } \\
\text { Total } \\
\% \\
\text { Affected } \\
\text { Total } \\
\%\end{array}$ & $\begin{array}{c}5 \\
163 \\
3 \cdot 1 \\
4 \\
163 \\
2 \cdot 5\end{array}$ & $\begin{array}{c}6 \\
806 \\
0.7 \\
5 \\
888 \\
0.6\end{array}$ & $\begin{array}{c}6 \\
780 \\
0 \cdot 8 \\
6 \\
827 \\
0.7\end{array}$ \\
\hline
\end{tabular}

(paternal or maternal) of the relatives (table 12), and to the side of the defect and association with cleft palate for CL(P) patients (table 13). Only CL(P) relatives are counted as affected when the proband is $C L(P)$ and similarly for CP. In general, the results are very similar to other studies. The following may be noted.

The frequency decreases sharply from first to second degree relatives, but remains the same for second and third degree relatives, particularly for CL(P).

There is absolutely no variation in the frequency of clefts in relatives according to the sex of the probands in CL(P). In CP, there is a significant increase in first degree relatives when the proband is a male $(0.05>p>0.02)$ but not in other relatives.
There is no difference between paternal and maternal relatives of all degrees of kinship in CL(P) or CP, as observed by Bingle and Niswander. ${ }^{21}$

There is no significant variation in the frequency of $\mathrm{CL}(\mathrm{P})$ in relatives of $\mathrm{CL}(\mathrm{P})$ probands, according to the side of the defect and association with CP.

\section{FREQUENCY OF ALTERNATE TYPE CLEFTING}

IN SIBS AND FIRST COUSINS

To test the existence of an association between the two types of clefts, the frequency of 'alternate type'* (AT) clefting in sibs and first cousins of the probands was compared with the frequency in French live newborns.

${ }^{*} \mathrm{CP}$ when the proband was affected with $\mathrm{CL}(\mathrm{P})$ and vice versa, terminology which was proposed by Chabora and Horowitz.22 
TABLE 13 Frequency of $C L(P)$ in relatives of $C L(P)$ patients according to side of defect and association with $C P$

\begin{tabular}{|c|c|c|c|c|c|}
\hline & & Relatives & 1st degree & 2nd degree & 3rd degree \\
\hline \multirow{6}{*}{$\begin{array}{l}\text { Association } \\
\text { with CP }\end{array}$} & \multirow{2}{*}{$\mathrm{CL}$} & Affected & 13 & 6 & 4 \\
\hline & & Total & 440 & 1256 & 1139 \\
\hline & \multirow{3}{*}{$\mathbf{C L}+\mathbf{P}$} & $\%$ & $3 \cdot 0$ & 0.5 & 0.4 \\
\hline & & Affected & 35 & 14 & 14 \\
\hline & & Total & 1423 & 3674 & 3719 \\
\hline & \multirow{3}{*}{ Unilateral } & $\%$ & $2 \cdot 4$ & 0.4 & 0.4 \\
\hline \multirow{6}{*}{$\begin{array}{l}\text { Side of } \\
\text { defect }\end{array}$} & & Affected & 32 & 11 & 16 \\
\hline & & Total & 1419 & 3715 & 3697 \\
\hline & & & $2 \cdot 3$ & 0.3 & 0.4 \\
\hline & Bilateral & Affected & 16 & 9 & 2 \\
\hline & & Total & & 1215 & 1161 \\
\hline & & $\%$ & $3 \cdot 6$ & $0 \cdot 7$ & 0.2 \\
\hline
\end{tabular}

TABLE 14 Comparison of frequency of AT clefting in sibs and first cousins of probands and frequency in the general population

\begin{tabular}{|c|c|c|c|c|c|c|c|c|c|}
\hline \multirow[t]{3}{*}{ Proband } & \multicolumn{3}{|l|}{ Sibs } & \multicolumn{3}{|c|}{ First cousins } & \multicolumn{3}{|c|}{ Sibs + first cousins } \\
\hline & \multirow[t]{2}{*}{ Total } & \multicolumn{2}{|l|}{ Affected } & \multirow[t]{2}{*}{ Total } & \multicolumn{2}{|l|}{ Affected } & \multirow[t]{2}{*}{ Total } & \multicolumn{2}{|l|}{ Affected } \\
\hline & & Expected* & Observed & & Expected* & Observed & & Expected* & Observed \\
\hline $\begin{array}{l}\text { CL(P) } \\
\text { CP } \\
\text { Total }\end{array}$ & $\begin{array}{r}927 \\
350 \\
1277\end{array}$ & $\begin{array}{l}0.324 \\
0.287 \\
0.611\end{array}$ & $\begin{array}{l}1 \\
2 \dagger \\
3 \dagger\end{array}$ & $\begin{array}{l}4858 \\
1495 \\
6353\end{array}$ & $\begin{array}{l}1 \cdot 700 \\
1 \cdot 226 \\
2 \cdot 926\end{array}$ & $\begin{array}{l}3 \\
3 \\
6\end{array}$ & $\begin{array}{l}5785 \\
1845 \\
7630\end{array}$ & $\begin{array}{l}2 \cdot 024 \\
1 \cdot 513 \\
3 \cdot 537\end{array}$ & $\begin{array}{l}4 \\
5 \dagger \\
9 t\end{array}$ \\
\hline
\end{tabular}

*If there is no association between $\mathrm{CL}(\mathrm{P})$ and $\mathrm{CP}$.

tSignificant (right tailed Poisson).

Sibs and first cousins were chosen because (1) they belong to the same generation as the proband, and thus represent a homogeneous population comparable to the general population for which the frequency has been estimated; (2) the diagnosis is easy to verify in most cases, especially in sibs; and (3) there are no problems of biased sampling resulting from the natural and social selection against people with $\mathbf{C L} \pm \mathbf{P}$ as would be the case among parents and grandparents.

Since the total number of sibs and first cousins is large and the expected frequencies of $\mathrm{CL}(\mathrm{P})$ and $\mathrm{CP}$, if there is no association, is small, the expected numbers of AT sibs and first cousins follow a Poisson distribution.

The results are given in table 14. Among the 927 sibs of $\mathrm{CL} \pm \mathrm{P}$ probands, one has a cleft palate. If there is no association, the expected number is 0.324 $(927 \times 0.00035)$ which represents the parameter of the Poisson distribution. The probability that at least one has cleft palate is 0.277 (right tailed distribution), which is not significant. In first cousins, the observation of three CP among 4858 is not significantly greater than the 1.700 expected $(p=0 \cdot 243)$. When both sibs and first cousins are added, the comparison is still not significant $(p=0 \cdot 146)$. Among the 350 sibs of CP probands, two have $C L(P)$, which is significantly greater than the 0.287 expected $(p=0.034)$. Among the 1495 first cousins, the observed number of three $\mathbf{C L} \pm \mathbf{P}$ is not significantly greater than the 1.226 expected $(p=0 \cdot 126)$, but when sibs and first cousins are added the excess is clearly significant $(p=0.019)$.

When all the probands are pooled, the observed number of AT sibs is three, which is about five times greater than the expected number, $0 \cdot 611(\mathrm{p}=0 \cdot 024)$. The observed number of AT first cousins is six which is about twice as many as the expected number, 2.926, but is not significant $(p=0.077)$. When sibs and first cousins are added, the observed number of nine AT clefts is clearly significant ( $\mathrm{p}=0.011)$.

\section{Discussion}

After this detailed description, we shall only discuss a few points of particular interest.

POP ULATION FREQUENCY

The population incidences for $\mathrm{CL}(\mathrm{P})$ and $\mathrm{CP}$ may appear low in comparison with other European populations, among which the incidences are in general a little more than 0.001 for $C L(P)^{23}$ and around 0.005 for CP. This discrepancy cannot be solely the result of the exclusion of malformation syndromes, as seen in table 1.

Since our low frequency cannot result from missing diagnoses, especially for $\mathrm{CL}(\mathrm{P})$, we must 
conclude that the frequency of clefts, particularly $\mathrm{CL}(\mathrm{P})$, is lower in France than in other European countries. The same discrepancy has been found for neural tube defects. ${ }^{24}$

\section{SEX RATIO}

The excess of males in CL(P) and of females in $\mathrm{CP}$ has been known for a long time. Under the multifactorial model, this would be the result of a shift between the distribution of liabilities of males and females. ${ }^{25}$ In CL(P) the distribution of liability for males would be shifted to the right of that for females, resulting in a higher proportion of males. Niswander $e^{2} a^{26}$ reported a decrease in sex ratio in affected as well as in unaffected sibs as the number of affected subjects increased in families. They concluded that these observations were consistent with a two-threshold model: subjects whose liability exceeds the first threshold would be affected by CL(P) and those with liabilities exceeding the second threshold would be aborted early in development. As the number of affected children per sibship increases, there would be a greater shift in liability in males than in females. The result would be that relatively more male embryos are aborted, with consequent observed shifts in the sex ratio among affected as well as normal subjects. The same decrease in sex ratio was observed by Bear ${ }^{16}$ but his conclusions were completely opposite to those of Niswander et al. ${ }^{26}$ Observing a decrease in abortion rates with the number of affected subjects in sibships, he concluded that there was no argument in support of Niswander's model and that these results, combined with those of other investigators, indicated the existence of inherited factors reducing the abortion frequency in the sibships of $C L(P)$ index cases. These reductions would apply only to female embryos, explaining the increase in sex ratio. However, our results suggest that the decrease in abortion rate with the number of affected subjects in sibships is very likely an observation bias. The abortion frequency decreases as sibship size increases, in cleft sibships as well as in control sibships. Since the number of affected subjects is positively correlated with sibship size, the reduction of abortion rate is very likely a consequence of this trivial correlation and not of a biological phenomenon. In fact, there is little need to postulate increased or decreased abortion frequencies to account for the reduction in sex ratio with the number of affected subjects in sibships. Whatever the mode of inheritance, the more affected subjects in a sibship, the more genetic factors are involved. If these genetic factors are not sex linked, the sex ratio in families with several affected sibs would be expected to be the same as in the general population.
MATERNAL EFFECTS

In reviewing the genetics of $\mathrm{CL}(\mathrm{P})$ and $\mathrm{CP}$, Fraser $\stackrel{2}{\stackrel{\mathrm{P}}{\Rightarrow}}$ stated that up till then no maternal effect had been $\stackrel{\overline{\vec{S}}}{2}$ demonstrated. Bingle and Niswander, ${ }^{21}$ studying theo data from 16 investigators, compared the incidence음 of clefts in maternal and paternal half sibs and did $\overline{\bar{m}}$ not find any difference. They also compared the $\mathbb{Q}$ incidence in maternal and paternal first cousins and found the same figures. Similar results are obtained ${ }_{\overrightarrow{ }}^{\text {s }}$ in our study.

The only positive maternal effect seems to be the $\overrightarrow{-}$ increased frequency of epileptic mothers of $\mathrm{CL}(\mathrm{P}) \stackrel{\mathrm{N}}{\mathcal{W}}$ cases compared to the control group. Shapiro et ll $^{27}$ found that epileptic mothers had a higher frequency 0 of malformed children than non-epileptic mothers, $\overrightarrow{0}$ with a relative risk of $1 \cdot 6$. Among these malfor- $-\overrightarrow{-}$ mations, cleft anomalies were more common than in controls. Their data also suggested that epilepsy itself and not the anticonvulsant drugs was respon- $\vec{T}$ sible for the increased risk, which is confirmed by $\mathbb{T}$ our study. In particular, there was no association of the malformation with antenatal exposure to the drugs when they were taken for reasons unrelated to epilepsy.

FREQUENCY OF CLEFTS IN RELATIVES

The results are, on the whole, very similar to those obtained by other investigators. These results will be discussed fully in a subsequent paper on segregation analysis.

FREQUENCY OF ALTERNATE TYPE CLEFTING IN SIBS AND FIRST COUSINS

Our results tend to show an association between $C L(P)$ and $C P$, which has been denied by most? authors except Rank and Thomson ${ }^{28}$ and Chabora and Horowitz. ${ }^{22}$ However, these latter authors usedo pooled population data with differing incidences of 3 clefting which obviously included malformation syndromes.

Although these syndromes have been excluded from our data, we cannot be sure that among의 families with both types of clefts there are not some $>$ cases of Van der Woude syndrome without lip pits in several affected members, as has been previouslyñ reported. ${ }^{29}$ Moreover, the significant association is based on small numbers and needs a larger data base $\mathcal{N}$ to prove this point. If this association exists, it means $\tilde{N}$ that there are certain common aetiological factors, genetic or environmental, responsible for eacho malformation, and not, as claimed by Chabora and Horowitz,"22 "that CL(P) and CP alleles are one and? the same, or that they are at least closely linked".

We thank Drs D Pellerin, P Petit, and J L Grignon who arranged for us to interview the families of the 
patients attending their departments, all those who provided data for the estimation of the frequency in the population, and Dr S R Berenberg (International Children's Center) for revision of the manuscript.

\section{References}

1 Fogh-Andersen P. Inheritance of harelip and cleft palate. Copenhagen: Busck, 1942.

2 Kobayasi Y. A genetic study of harelip and cleft palate. Jpn J Hum Genet 1958;3:73-107.

3 Curtis E, Fraser FC, Warburton D. Congenital cleft lip and palate: risk figures for counseling. Am J Dis Child $1961 ; 102: 853-7$.

4 Woolf CM, Woolf RM, Broadbent TR. A genetic study of cleft lip and palate in Utah. Am J Hum Genet 1963;15: 209-15.

${ }^{5}$ Carter CO. The inheritance of common congenital malformations. In: Steinberg AG, Bearn AG, eds. Progress in medical genetics. Vol 4. New York: Grune and Stratton, 1965:59-74.

6 Fujino H, Tashiro H, Sanui Y, Tanaka K. Empirical genetic risk among offspring of cleft lip and cleft palate patients. Jpn J Hum Genet 1967;12:62-8.

7 Woolf CM. Congenital cleft lip: a genetic study of 496 propositi. J Med Genet $1971 ; 8$ :65-83.

8 Czeizel A, Tusnady G. A family study of cleft lip with or without cleft palate and posterior cleft palate in Hungary. Hum Hered 1972;22:405-16.

9 Chung CS, Ching GHS, Morton NE. A genetic study of cleft lip and palate in Hawaii. II. Complex segregation analysis and genetic risks. Am J Hum Genet 1974;26: 177-88.

10 Bear JC. A genetic study of facial clefting in Northern England. Clin Genet 1976;9:277-84.

11 Welch J, Hunter AGW. An epidemiological study of facial clefting in Manitoba. J Med Genet 1980;17:127-32.

12 Fraser FC. The genetics of cleft lip and cleft palate. $A m \mathrm{~J}$ Hum Genet 1970;22:336-52.

13 Chung CS, Rao DC, Ching GHS. Population and family studies of cleft lip and palate. In: Melnick M, Bixler D, Shields ED, eds. Etiology of cleft lip and cleft palate. Progress in clinical and biological research. Vol 46. New York: Alan R Liss, 1980

14 Melnick M, Shields ED, Bixler D, Conneally PM. Facial clefting: an alternative biologic explanation for its complex etiology. Birth Defects 1977;13:93-112.
15 Briard ML, Feingold J, Bonaiti-Pellie C, Lapeyre F, Frézal J, Varangot J. Fréquence des malformations à la naissance: étude d'une maternité parisienne. Arch Fr Pediatr 1975;32:123-38.

16 Bear JC. Spontaneous abortion, sex ratio and facial cleft malformations. Clin Genet 1978;13:1-7.

17 Fraser GR, Calnan JS. Cleft lip and palate: seasonal incidence, birth weight, birth rank, sex, site, associated malformations and parental age. Arch Dis Child 1961 ;36: 420-3.

18 Woolf CM. Parental age effect for cleft lip and palate. Am J Hum Genet 1963;15:389-93.

19 Feingold J, Frézal J, Briard-Guillemot ML. Résultats d'une enquête sur le poids de naissance et le poids du placenta. Arch Fr Pediatr 1970;27:785-96.

20 Lutz KR. Birth weights in cleft palate. Cleft Palate Bull 1959;9:47.

21 Bingle GJ, Niswander JD. Maternal effects in human cleft lip and palate. Am J Hum Genet 1977;29:605-9.

22 Chabora AJ, Horowitz SL. Cleft lip and cleft palate: one genetic system. Oral Surg 1974;38:181-6.

23 Melnick M, Bixler D, Fogh-Andersen P, Conneally PM. Cleft lip \pm cleft palate: an overview of the literature and an analysis of Danish cases born between 1941 and 1968. Am J Med Genet 1980;6:83-97.

24 Le Merrer M, Briard ML, Demenais F, Feingold $J$, Frézal J. Etude épidémiologique et génétique du spina bifida. Arch Fr Pediatr 1980;37:521-5.

25 Carter CO. The inheritance of congenital pyloric stenosis. Br Med Bull 1961;17:251-4.

26 Niswander JD, Maclean CJ, Chung CS, Dronamraju D. Sex ratio and cleft lip with or without cleft palate. Lancet 1972;ii:858-60.

27 Shapiro S, Slone D, Hartz SC, et al. Anticonvulsivants and parental epilepsy in the development of birth defects. Lancet $1976 ; \mathbf{i}: 272-5$.

28 Rank BK, Thomson JA. Cleft lip and palate in Tasmania. Med J Aust 1960;2:681-9.

29 Cervenka J, Gorlin RJ, Anderson VE. The syndromes of pits of the lower lip and cleft lip and/or palate: genetic considerations. Am J Hum Genet 1967;19:416-32.

Requests for reprints to $\operatorname{Dr} M$ L Briard, Unité de Recherches de Génétique Médicale, Hôpital des Enfants-Malades, 149 rue de Sèvres, 75730 Paris Cédex 15, France. 